УДК $821.111-27 " 17 / 21 "$

DOI: $10.24144 / 2617-3921.2019 .17 .203-211$

Дмитро Дроздовський кандидат філологічних наук, старший науковий співробітник відділу світової літератури Інституту літератури ім. Т.Г. Шевченка НАН Украӥни ORCID 0000-0002-2838-6086 м. Київ, Україна тел.: 0675574443, e-mail: drozdovskyi@ukr.net

\title{
Дискурс «розуму» в британському постпостмодерністському романі: між свідомістю й фізіологією тіла
}

Анотація. $У$ статті окреслено дискурс розуму як чинник постпостмодерністського британського роману. Проаналізовано специифіку мислення персонажів романів, у яких головні герої наділені особливим «ресурсом розуму», щуо дає можливість уникати соціальної напруженості, конфліктів $і$ бачити світ у єдності біофізичних і соціально-психологічних прочесів $i$ феноменів. Доведено, щзо в британському літературному постпостмодернізмі важливе значення відіграє реактуалізація філософських ідей Гегеля та Дж. Локка. Досліджено, щзо унікальні розумові здібності персонажів дають можливість сприймати зовнішню реальність в одивнений спосіб. Специифіка світосприйняття протагоністів дає підстави говорити про експлікацію в сучасному британському романному дискурсі філософії нового гуманізму. Визначено кореляції між простором тілесності та розумом у постпостмодерністському романі 2000-2010-х рр.

Ключові слова: постпостмодернізм, сучасний британський роман, розум, аутизм, мислення, тіло.

Abstract. In the paper, the discourse of mind as a factor in the postpostmodernistic British novel has been outlined. The specificity of thinking of the characters of novels, in which the main characters are endowed with a special resource of reason, which makes it possible to avoid social tensions, conflicts and see the world in the unity of biophysical and socio-psychological processes and phenomena, has been analyzed. It is proved that in British literary postpostmodernism, the re-actualization of the philosophical ideas of Hegel and John Locke plays an important role. It was investigated that the unique mental abilities of characters make it possible to perceive external reality in a monolithic way. The specificity of world perception of protagonists gives grounds to define the explication in contemporary British novelistic discourse of the philosophy of new humanism. The correlations between corporeality and minc in the postpostmodernistic novel of 2000-2010-s have been determined. In the paper, the philosophical parameters of thinking of characters of British post-postmodernistic 
novel have been spotlighted as ones that determine objectified and truthful from the point of view of historicity and sociality representing of reality and visualize a range of political, social and economic problems. In contemporary English novel, there is a critique of social institutions, discourse of power, political doctrines, etc. inherent in the traditions of realistic prose. In the paper, the author has investigated the specific representation of autistic thinking in contemporary postpostmodernistic novel. The novel "The Curious Incident of the Dog in the NightTime" by M. Haddon is in the center of attention. In the post-postmodernistic novel, the construction of the world takes place in accordance with the concept of the psychic world as one that contains hidden spaces that can be actualized in situations of uncertainty, during strong shocks, etc. Christopher, the protagonist of $M$. Haddon's novel, has a special way of thinking inherent in the strategy to objectify reality laying it out into basic causal elements. At the same time, the protagonist represents a special type of scientific mind seeking to learn the world in accordance with the concept of prime numbers and avoiding any form of emotionality. Originality of the research is connected with the revelation of the philosophical parameters of thinking of characters, which is objectified and truthful from the point of view of historicity and sociality in the aspect of representing reality, which visualizes a range of political, social and economic problems. In contemporary English novel, there is a critique of social institutions, discourse of power, political doctrines, etc. inherent in the traditions of realistic prose. In the paper, it has been analyzed the features of post-realism in contemporary novel of Great Britain tracing historical dynamics of realistic tendencies and emphasizing the specific features of the outlook of postpostmodernistic characters, who seek to avoid conflicts and injuries using a special type of world perception, which makes impossible the privilege of emotional over rational.

Keywords: post-postmodernism, contemporary British novel, mind, autism, consciousness, body.

Вступ. Для персонажів романів “Старий жарт” Дж. Джонстон [4], "Дивний випадок із собакою вночі" М. Геддона [3], "Угамуйте мене" М.Дж. Гайленд [2], “Субота” [8], “Амстердам” [6] I. Мак’юена та ін. представників британського (англійського, ірландського та ін.) роману тема пізнання суб'єктом реальності набуває особливого значення в постпостмодерністському дискурсі. Мислення героїв репрезентоване як таке, у якому знаходять своє відображення відлуння наукового (біологічного, фізичного, математичного) та гуманітарного дискурсів. Світогляд персонажів згаданих романів оприявнює проблему гібридизації, про яку говорять Б. Латур [12] і А. Менцвель [9], а також спонукають до розгляду світогляднофілософських параметрів літературного постпостмодернізму через призму постпросвітницьких тенденцій, які набувають реактуалізації в сучасному 
англійському романі, заторкуючи питання пам'яті, сприйняття, знання, ідентичності, соціальної інтеракції та комунікації тощо.

Методологія та методи дослідження. У роботі використано підходи герменевтичного аналізу літературних текстів в аспекті вивчення психології персонажів, особливостей світоглядних параметрів та філософських настанов героїв постпостмодерністського роману. Крім того, у студії наявне полемічне продовження ідей, висловлених у працях істориків літератури, які займалися вивченням британського роману XX-XXI ст. (В. Генієва, Д. Лодж, М. Бредбері).

Виклад основного матеріалу дослідження. Дж. Локк наголошує на важливості пізнання розуму (того, як відбувається сприйняття різних феноменів, чи можуть бути ідеї й поняття вродженими, у чому полягає специфіка сприйняття ідеї Бога тощо), зазначаючи, що його передусім цікавлять епістемологічні питання. Проте протагоністи романів “Субота” й “Дитина в часі” I. Мак'юена задаються питаннями про те, чому виникають хиби в аналізі реальності мозком, чому люди здатні до різних інтерпретацій тієї самої події. Для Кристофера з роману “Дивний випадок із собакою вночі” відповідь полягає в наявності у людини емоцій, які впливають на інтерпретаційні здібності й викривлюють реальність в інтерпретації. Дж. Локк писав, що “моєю метою є вивчення походження, правдивості та міри людського знання разом із засадами та ступенями віри, думки і згоди. Наразі я не вдаватимуся до розгляду ума в його фізичному аспекті та не перейматимуся 3'ясуванням його сутності й порухів нашого духу чи змін у тілі, внаслідок яких наші тілесні органи запроваджують відчуття і розум отримує ідеї <..>. Для досягнення наміченої мети мені досить розглянути пізнавальні людські здібності, а також їхнє застосування для об’єктів, 3 якими мають справу" [5, с. 28]. Натомість дискурс постпросвітництва, дискусія про вродженість чи набутість знання (ідей, уявлень, понять) у річищі британського літературного постпостмодернізму переходить у площину нейрофізіологічну, залучаючи до аналізу цієї проблеми дані 3 царини біології, генетики та ін. По суті, маємо вияви постпросвітницької парадигми, позаяк персонажів романів культивують розум і знання, а також ставлять питання про те, як розум може допомогти людині в ситуації зустрічі 3 невідомим, коли потрібно миттєво реагувати на те, що досі не було елементом життєсвіту людини. Сам розум може бути безпорадним у ситуації зустрічі з невідомим, тому потрібно розвивати в собі певні аналітичні уміння, які постають важливим чинником соціальної адаптації, зокрема ж для персонажів, які мають особливі потреби на кшталт Кристофера. Ще Дж. Локк зауважував: “Пізнавши власні сили, ми ліпше знатимемо, у яких випадках можна розраховувати на успіх. Коли ми добре обстежимо сили власного ума й оцінимо те, чого від них можна чекати, то в нас не виникне бажання, 3 одного боку, лишатися бездіяльними i, не сподіваючись пізнати будь-що, навзагал дати спокій своїм думкам, а з другого боку, ми не будемо піддавати 
сумніву все без винятку та заперечувати знання в цілому на підставі незрозумілості деяких речей” [5, с. 32].

У постпостмодерністському романі концепт правди набуває особливої значущості: 3 одного боку, персонажі розуміють, що правди неможливо досягнути в онтологічному смислі, позаяк емоції $\epsilon$ тим чинником, який перешкоджає у створенні об'єктивної картини світу. 3 другого боку, у світогляді постпостмодерністських персонажів представлено такі поняття, як “Бог”, “першопочаток” Всесвіту, ідеї, пов’язані з теорією великого вибуху тощо. Розмисли про ці теорії дають можливість припустити наявність онтологічної правди, яка існує поза гносеологічними здібностями людини. Дж. Локк, до речі, ніколи не заперечував Бога, а навпаки, прагнув довести підставовість цієї ідеї, iї онтологічну сутність. Англійський філософпросвітник зазначав: “Якщо котрусь ідею можна уявити природженою, то такою з багатьох причин щонайперше можемо вважати ідею Бога. Важко ж бо осягнути, в який спосіб природжені моральні принципи здатні існувати без природженої ідеї божества. Без поняття про законодавця неможливо мати уявлення про закон і обов'язково його дотримуватися" [5, с. 116].

Неправда - це незбіг між тим, що має місце насправді, й тим, як про реальність хтось відгукується. Порушення цієї єдності або “принципу простих чисел» - подразник для юнака-аутиста, який результує інтенсифікацією захисних реакцій. У такому разі, якщо припустити, що світ родини, зокрема, його батьків - це простір, побудований навколо любові, то Кристофер є тим, хто відмовляється від любові як чинника непорозумінь у світі. Любов для юнака означає небезпеку в зовнішній реальності, бо вона спонукає людей брехати, аби бути поруч. Ідеться про те, що любов має різні вияви інтенсивності: інколи люди, уже не маючи попередніх почуттів, живуть ніби за інерцією, підтримуючи гармонію в родині, проте це відбувається лише на поверховому рівні. Насправді члени родини змушені вдаватися до різних обманів і маніпуляцій. Для Кристофера така поведінка апріорі неприпустима, тому він є персонажем, який не може прийняти любові від інших.

У британському літературному постпостмодернізмі ідеї, пов’язані 3 категорією часу, так само мають особливу значущість. По-перше, така увага до цієї категорії зумовлена особливостями історії англійської літератури, у річищі якої теми ревізіювання минулого набуває епістемологічної значущості. По-друге, категорія часу постає важливим елементом просвітницького й, відповідно, постпросвітницького дискурсів. По-третє, досягнення сучасної фізики та астрофізика, був новітніх теорій, зокрема про суперструнну реальність, став поштовхом до залучення цих результатів до гуманітарного дискурсу, змінюючи водночас i світоглядну парадигму британського роману (“Хмарний атлас” Д. Мітчелла).

Звернення до просвітницьких позицій та ідей детерміноване прагненням постпостмодернізму встановити втрачений у постмодернізмі 
порядок речей. Історія англійської філософії засвідчує, що в цій традиції ідеї емпіричної філософії мали важливе значення для формування національного характеру й певного типу світогляду. Робінзон Крузо постає класичним героєм просвітницького типу, чия раціональність допомагає облаштувати життя на безлюдному острові. Гуллівер Дж. Свіфта постає іншим типом «розуму», який показує хиби раціонального пізнання дійсності. Проте навіть попри використання в «Мандрах Гуллівера» сатиричних та іронічних форм зображення «раціо», складно заперечити просвітницьку сутність наративу, у якому концепція розумового пізнання дійсності розгортається в полемічній площині. У XXI ст. Велика Британія переживає значні політичні та соціально-економічні потрясіння (BREXIT, проблеми з мігрантами тощо), які вияскравлюють потребу віднайти «істину» в тому, що відбувається. Велика Британія виходить із $€ С$, формуючи власний геополітичний курс, водночас BREXIT постає фіналом багаторічної кампанії, яка відбувалася в британських медіа. Крім того, у 2018 р. Можна з упевненістю сказати, що досі достеменно не відомо, чи проект «BREXIT» буде реалізовано повною мірою. 3 одного боку, Велика Британія натрапляє на широкий спектр соціально-політичних та економічних проблем, які детермінують відчуття кризової невпевненості в тому, що відбувається. 3 другого боку, саме філософська традиція Великої Британії містить значний «раціоцентричний» потенціал, пов'язаний із намаганням верифікувати все, що відбувається навколо, через емпірику. Особливості такого світогляду знаходять свою реалізацію в успішності британської медицини, в дослідженнях у царині фізики, хімії, біології, нанотехнологій та астрофізики тощо. У такому разі сучасний роман Великої Британії прагне словесно візуалізувати комплекс проблем, які хвилюють сьогоднішнє суспільство. Роман постає відповіддю на ті тенденції, що мають місце в суспільній свідомості і які загалом пов'язані 3 гібридизацією реальності навколо людини. Медіаконтент - один із найінтенсивніших чинників, що сприяє такій гібридизації, популяризуючи науково-технологічні досягнення країни в масовому сприйнятті.

Сучасний британський роман $є$ продовженням соціально-політичних процесів; у ньому відбувається спроба з'ясувати, чи може історичний досвід допомогти в розв'язанні проблем сьогодення. У постпостмодерністському романі відбувається експлікація персонажів, які, покладаючись на розум, водночас утверджують право на «похибку». Причиною похибки може бути як особливість психофізіологічної природи людини (вплив емоцій на прийняття рішень, особливості темпераменту, що визначають характер, а все це разом детерміноване біохімічною особливістю i нейрогуморальною регуляцією організму), так і недостатність пізнання реальності, обмеженість як людського мозку, так і інструментів осягнення дійсності. Важливо, що в більшості аналізованих у цій праці англійських романів відбувається осмислення поняття «Бога», який жодним чином не заперечується, подібно до просвітницької доби: у філософських трактатах Дж. Локка постульовано, 
що ідея «Бога» $є$ однією 3 найбільш беззаперечних. Водночас у романах представлено гносеологічну проблему: неможливість пізнати реальність достеменно, неможливість у силу біологічних причин з'ясувати, чи не помиляється персонаж в інтерпретації фрагменту дійсності, чи може він достеменно пригадати, що відбувалося 3 ним у минулому, як уявлення про досвід минулого впливає на сьогодення тощо. Зазначені проблеми особливо актуальні в річищі ідей постпостмодернізму. Персонажі постпостмодерністського роману поєднують у собі прагнення перевіряти дійсність, послуговуючись принципом леза Оками, вони висловлюють іронію та скепсис стосовно політичних подій, водночас постпостмодерністські персонажі здатні елімінувати в собі все, що не стосується форм раціонального аналізу, та мінімізувати вплив емоцій у кризові ситуації. 3 погляду на це модель аутичного мислення експлікована в романах як ідеалістична: персонаж-аутист у романі «Дивний випадок із собакою вночі» наділений стереотипно-ідеалістичною здатністю аналізувати реальність навколо себе. Соня Лофтіс у праці «Imagining Autism» [14] показує, що такий принцип зображення аутистів у літературі не відповідає справжній поведінці аутистів. Водночас Кристофер у романі Марка Геддона постає символом постпостмодерністського часу, у якому людина поєднує в собі різні світоглядні позиції, філософські підходи до сприйняття життя: у кожному 3 них може міститися елемент, потрібний для правильної поведінки в нестандартній ситуації. Реальність постпостмодерністського роману розгортається як потенційно нелінійна, нестандартна, у якій практично неможливо керуватися наперед заданими досвідом формулами поведінки. Успішні моделі поведінки в одній ситуації недієві в іншій.

Постпостмодерністський персонаж - це «іронічний цинік» та «ідеалістромантик», здатний пізнавати дійсність у всій повноті смислів, аналізуючи реальність в не окремих аспектах, а цілісно. Такий підхід можливий за умови, якщо персонажі володітимуть достатнім знанням точних наук, які водночас накладаються на особливості гуманістичного світогляду, витворюючи нову світоглядно-філософську модель сприйняття дійсності в постпостмодернізмі.

Зауважимо, що концепція гегелівського «зняття» актуальна в сучасному літературознавстві в аспекті окреслення тенденцій британського постпостмодерністського роману. «Зняття» передбачає наявність додаткового «ресурсу» людяності, краси, добра, розуму, що 3 позицій просвітницької парадигми дають можливість побудувати краще суспільство, у якому важливо підтримувати гуманістичні цінності. Ресурс «розуму» постає ключовим в аналізованих у статті романах. В англійському романі 2000-2010-х рр. особливу увагу приділено дослідженню людини, зокрема в аспекті розуміння природи свідомості (інтелекту) й тілесності. Розум і тіло, які традиційно розведені в мистецькій площині, перебувають у своєрідній єдності в постпостмодерністському романі. Важливо 3'ясувати, у чому ж полягає нова репрезентація розуму й тіла. 
Протагоніст роману «Дивний випадок із собакою вночі» М. Геддона постає персонажем, здатним «одивнено» дивитися на зовнішній світ. Неврологічна хвороба (брак дзеркальних нейронів) робить юнака не таким, як більшість 3 оточення. Генетична особливість створює 3 Кристофера «простака» XXI століття, який не приймає соціальних законів, не розуміє форм світосприйняття, що панують навколо нього. Світ дорослих людей зображено в романі як простір неправди, яку протагоніст «Дивного випадку...» не приймає в силу генетичної специфіки. Особливості геному унеможливили розуміння неправди, коли сказане не дорівнює дійсності. У цьому полягає додатковий «ресурс розуму» Кристофера: генетична хвороба робить його носієм нового типу мислення, у якому світ функціонує як Всесвіт, як мультиверсум різних процесів і явищ. Головне: навчитися визначати форми зв'язку між різними просторами множинної реальності, у якій перебуває персонаж роману Марка Геддона.

У романі «Угамуйте мене» М.Дж. Гайленд представлено образ юнакаполіграфа, який так само, як i Кристофер, наділений «додатковим» розумовим ресурсом. Джон має особливий організм, який реагує нудотою на брехню $з$ боку інших. Тіло постає маркером (ідентифікатором, лакмусом i одночасно реакцією) на результат когнітивних операцій. Навколишня реальність проходить аналіз у свідомості персонажа, проте результатом аналітичної роботи постає фізіологічна відповідь. Тіло пов'язане зі свідомістю, а саме мислення персонажа позначене здатністю на інтуїтивному рівні (природа цього явища не пояснена у творі) «зчитувати» істинний смисл повідомлень під час комунікативної взаємодії. Особливий інтелект Джона робить його «надлюдиною», яка так само, як і Кристофер у «Дивному випадку...», дивується, чому люди навколо персонажа постійно обманюють одне одного й схиляють інших казати неправду: це виявляється навіть у побутових розмовах і стосується життєвих дрібниць (як під час розмови бабусі з онуком).

Для Генрі Пероуна, протагоніста роману «Субота» I. Мак’юена, не існує бар'єру між свідомістю й тілом. Як нейрохірург, він розуміє, що $є$ зв'язок між тілом і свідомістю, проте фаховий лікар не може до кінця встановити, у який спосіб функціонує свідомість: чи це результат роботи тіла як біологічного об'єкта, у якому відбуваються фізичні й хімічні процеси, чи свідомість виникає у тілі, проте є окремим феноменом, який має не лише фізико-хімічну природу. Генрі розвиває ідеї античного філософа Платона, який розмежовував тіло та «кволію», якою схарактеризував «емоційне тіло» людини. Генрі розуміє навколишній світ через виявлення в ньому симптомів різних невралгічних захворювань, які дають можливість відчувати себе «надлюдиною». «Додатковий розум» Генрі Пероуна полягає у високому професіоналізмі, у здатності використовувати набуті професійні навички на уміння не лише в операційній. Герой так само сприймає світ як такий, у якому люди приховують свою сутність, передусім хвороби, проте уважне 
ставлення до виявів тіла (наприклад, дрижання рук, зрештою, будь-які вияви пароксизму) дає можливість розуміти справжню причину поведінки інших.

Персонажі сучасного британського роману наділені «додатковим розумом», який дає їм можливість бути соціально адаптованішими й стійкішими в конфліктних ситуаціях. Аналізовані персонажі художніх творів виявляють надчутливе розуміння інших, вони репрезентують якісно вищий щабель людства, хоч автори і вдаються до використання сатири та іронії в зображенні персонажів у різних комунікативних ситуаціях. У цьому полягає експлікація концепту гегелівського «зняття» в дискурсі сучасного британського роману 2000-2010-х pр., у якому акцентовано на проблематиці тіла й перетворенні його на джерело посилених або ж інтенсифікованих розумових здібностей. Кристофер у «Дивному випадку...» вважає, що причиною непорозумінь між людьми $\epsilon$ саме вияви емоцій, натомість десоматизація особистості й механізація дійсності допоможуть уникнути конфліктів і комунікативних труднощів.

Водночас аутичний розум персонажа напряму корелює 3 фізіологічними реакціями тіла: втручання в приватний простір юнака викликає в нього крик і нудоту, панічну атаку й інші реакції фізіологічного характеру. Розум, який у романі зображено в ідеалістичний спосіб, усе одно пов'язаний із тілом.

Висновки 3 дослідження. У такому разі в сучасному постпостмодерністському британському романі має місце дуалізація тілесності, яка, з одного боку, виявляє базові потреби людини, а 3 другого, в особливий спосіб пов'язана 3 розумовою діяльністю, зокрема в персонажів, яких у романах представлено як носіїв нового типу світорозуміння, що дає можливість пізнати дійсність (Всесвіт) у всій складності. Таке розуміння уможливлене особливим типом розуму, який взорує на математичні принципи доведення правил і для якого епістемологічною основою є світ точних наук. Наукові методи аналізу різних феноменів формують новий тип мислення, позбавлений множення беззмістовних сутностей. Принцип «леза Оками» постає важливим методологічним принципом функціонування такого розуму.

\section{ЛІТЕРАТУРА}

1. Блюменберг Г. Світ як книга. пер. 3 нім., передмова, коментарі В. Срмоленка. - К.: Лібра, 2005. - 544 с.

2. Гайленд М. Дж. Угамуйте мене [пер. з англійської Віктор Дмитрук]. Львів: Кальварія, 2008. - 248 с.

3. Геддон М. Загадковий нічний інцидент із собакою [пер. 3 англ. Анастасія Рогоза]. - Харків: Клуб сімейного дозвілля, 2016. - 221 с.

4. Джонстон Дж. Далеко ли до Вавилона? Старая шутка ; пер. с англ. Москва: Художественная литература, 1983. - 303 с. 
5. Локк Дж. Розвідка про людське розуміння. У чотирьох книгах. Кн. 1. Про неприродженість принципів та ідей ; з англ. Н. Бордукова. - Харків : Акта, 2002. - 154 с.

6. Макьюэн И. Амстердам. - Москва: “ФТМ”, “Эксмо”, 1998. - 140 с.

7. Мак’юен І. Спокута ; [пер. з англ. В. Дмитрук]. - Львів: Кальварія, 2008. $344 \mathrm{c}$.

8. Мак'юен І. Субота [пер. з англ. В. Дмитрук]. - Львів: Кальварія, 2007. $256 \mathrm{c}$.

9. Менцвель А. Антропологічна уява 3 пол. О.М. Вознюк. - К.: Юніверс, 2012. $-380 \mathrm{c}$.

10. Титаренко I.О., Лісовська I.В. Явище соціопатичної поведінки як проблема для існування й розвитку сучасного українського суспільства. завдання та можливості соціальної роботи і корекції // Вісник НТУУ “КПІ”. Політологія. Соціологія. Право. - Випуск 4 (8). 2010. [Електронний ресурс]. - Режим доступу: http://ela.kpi.ua/bitstream/123456789/5228/1/10\%20-\%204\%288\%29\%20\%2032.pdf

11. Bradbury Malcolm. The Modern British Novel. - London : Penguin Books, 1993. - 516 p. https://doi.org/10.1017/S0021875800018429

12. Latour Bruno. We Have Never Been Modern. - Cambridge, Massachusets : Harvard University Press, 1993. - 158 p.

13. Lazarus R.S., Folkman S. Stress, appraisal and coping. - New York : Springer, 1984. $-456 \mathrm{p}$.

14. Loftis Sonya Freeman. Imagining Autism: Fiction and Stereotypes on the Spectrum. - Indiana University Press, 2015. - 208 p.

15. Lodge David. The Consciousness and the Novel: Connected Essays. London: Secker \& Warburg, 2002. - 320 p.

16. Mitchell David. Cloud Atlas. - London: Random House, 2004. - 528 p. https://doi.org/10.1163/ej.9789004185753.i-378.79 